\title{
Surgical Site Infection in Patients Submitted to Orthopedic Surgery: The NNIS Risk Index and Risk Prediction
}

\author{
Flávia Falci Ercole ${ }^{1}$ \\ Tânia Couto Machado Chianca² \\ Denise Duarte ${ }^{3}$ \\ Carlos Ernesto Ferreira Starling ${ }^{4}$ \\ Mariângela Carneiro ${ }^{5}$
}

\begin{abstract}
The applicability of the risk index for surgical site infection of the National Nosocomial Infection Surveillance (NNIS) has been evaluated for its performance in different surgeries. In some procedures, it is necessary to include other variables to predict. Objective: to evaluate the applicability of the NNIS index for prediction of surgical site infection in orthopedic surgeries and to propose an alternative index. The study involved a historical cohort of 8236 patients who had been submitted to orthopaedic surgery. Statistical analysis was performed using multivariate logistic regression to fit the model. The incidence of infection was $1.41 \%$. Prediction models were evaluated and compared to the NNIS index. The proposed model was not considered a good predictor of infection, despite moderately stratified orthopedic surgical patients in at least three of the four scores. The alternative model scored higher than the NNIS models in the prediction of infection.
\end{abstract}

Descriptors: Nursing; Epidemiology; Orthopedic Procedures; Surgical Wound Infection; Risk Index.

\footnotetext{
${ }^{1}$ RN, Ph.D. em Parasitology, Adjunct Professor, Escola de Enfermagem, Universidade Federal de Minas Gerais, Belo Horizonte, MG, Brazil. E-mail: flavia.ercole@gmail.com.

${ }^{2}$ RN, Ph.D. in Nursing, Associate Professor, Escola de Enfermagem, Universidade Federal de Minas Gerais, Belo Horizonte, MG, Brazil. E-mail: tchianca@hotmail.com.

${ }^{3}$ Mathematician, Ph.D. in Statistics, Adjunct Professor, Instituto de Ciências Exatas, Universidade Federal de Minas Gerais, Belo Horizonte, MG, Brazil. E-mail: denisedsma@gmail.com.

${ }^{4}$ Physician, M.Sc., Hospital Vera Cruz de Belo Horizonte, MG, Brazil. E-mail: cstarling@task.com.br.

${ }^{5}$ Pharmacy-Biochemistry, Ph.D. in Parasitology, Associate Professor, Instituto de Ciências Biológicas, Universidade Federal de Minas Gerais, Belo Horizonte, MG, Brazil. E-mail: mcarneir@icb.ufmg.br.
}

Corresponding Author:

Flávia Falci Ercole

Rua Bernardino de Campos, 50/702

Bairro: Gutierrez

CEP: 30430-350 Belo Horizonte, MG, Brasil

E-mail: flavia.ercole@gmail.com 


\title{
Infecção de sítio cirúrgico em pacientes submetidos a cirurgias ortopédicas: o índice de risco NNIS e predição de risco
}

A aplicabilidade do Índice de Risco de Infecção Cirúrgica do National Nosocomial Infection Surveillance-NNIS tem sido avaliada quanto ao seu desempenho em diferentes cirurgias. Em alguns procedimentos, é necessária a inclusão de outras variáveis de predição. O objetivo deste estudo foi avaliar a aplicabilidade do Índice NNIS para a predição da Infecção de Sítio Cirúrgico em cirurgias ortopédicas e propor um índice alternativo. Realizouse estudo de coorte histórica em 8.236 pacientes submetidos a cirurgias ortopédicas. Utilizou-se modelo logístico multivariado para ajuste do modelo. A incidência de infecção foi de $1,41 \%$. Modelos de predição foram avaliados e comparados ao Índice NNIS. $O$ modelo proposto foi aquele que apresentou maior acúracia em classificar pacientes com e sem infecção. O Índice NNIS não foi considerado bom preditor de infecção, apesar de ter estratificado moderadamente os pacientes cirúrgicos ortopédicos em pelo menos três dos quatro escores. O modelo alternativo foi superior ao modelo NNIS na predição de infecção.

Descritores: Enfermagem; Epidemiologia; Procedimentos Ortopédicos; Infecção da Ferida Operatória; Indicador de Risco.

\section{Infección de sitio quirúrgico en pacientes sometidos a cirugías ortopédicas: el índice de riesgo NNIS y la predicción de riesgo}

\begin{abstract}
La aplicabilidad del Índice de Riesgo de Infección Quirúrgica del National Nosocomial Infection Surveillance-NNIS ha sido evaluada en cuanto a su desempeño en diferentes cirugías. En algunos procedimientos es necesaria la inclusión de otras variables de predicción. El objetivo de este estudio fue evaluar la aplicabilidad del Índice NNIS para la predicción de la Infección de Sitio Quirúrgico en cirugías ortopédicas y proponer un índice alternativo. Se realizó un estudio de cohorte histórica en 8.236 pacientes sometidos a cirugías ortopédicas. Se utilizó el modelo logístico multivariado para ajustar el modelo. La incidencia de infección fue 1,41\%. Modelos de predicción fueron evaluados y comparados al Índice NNIS. El modelo propuesto fue aquel que presentó mayor precisión en clasificar pacientes con y sin infección. El Índice NNIS no fue considerado un buen factor de predicción de la infección, a pesar de haber estratificado moderadamente a los pacientes quirúrgicos ortopédicos en por el menos tres de los cuatro puntajes. El modelo alternativo fue superior al modelo NNIS en la predicción de infección.
\end{abstract}

Descriptores: Enfermería; Epidemiología; Procedimientos Ortopédicos; Infección de Herida Operatoria; Índice de Riesgo.

\section{Introduction}

Surgical site infection (SSI) is the second or third most frequent infection among surgical patients. It is responsible for approximately $17 \%$ of all healthcarerelated infections(1). In Brazil, SSI ranks third among infections at health services and corresponds to between $14 \%$ and $16 \%$ of infections among hospitalized patients, with an $11 \%$ incidence rate ${ }^{(2)}$.

SSI related to orthopedic procedures represents a severe and catastrophic complication for patients, surgeons and hospital institutions, as an infection can extent the patient's hospitalization time by up to two weeks, double re-hospitalization rates, increase care costs by more than $300 \%$, besides causing important physical limitations that significantly reduce patients' quality of life after the surgery(3). Incidence levels of orthopedic SSI can range between 0.8 and $71 \%^{(4-9)}$.

SSI control constitutes a quality indicator of surgical patients' epidemiological surveillance. When identifying 
risk factors for patients or procedures that entail greater risks for infection, they can plan preventive actions and control strategies that result in decreased infection rates $^{(10)}$.

In the 1970's, the Center for Disease Control and Prevention ( $C D C)$ in Atlanta proposed the National Nosocomial Infection Surveillance (NNIS) System for the epidemiological surveillance of hospital infections $\mathrm{IHS}^{(11)}$.

The NNIS system has been developing indexes to predict infection risk in the surgical patient population, considering uncontrollable extrinsic and intrinsic risk factors. The range of risk factors in surgical patients needs to be used as a parameter to adjust the ratios ${ }^{(12)}$.

In 1981, the Study on the Efficacy of Nosocomial Infection Surveillance (SENIC) proposed an infection risk index for surgical patients. Later (1991), the SENIC Index was modified(12-15), suggesting the inclusion of baseline disease severity, assessed according to patients' clinical condition. This new NNIS Index establishes different surgical patients' infection risk(15-20).

Since 1997, studies demonstrate that the NNIS risk Index has not complied with its function of predicting the surgical site infection risk of specific procedures in an accessible, simple and objective way, with good discriminatory power(19-20).

The NNIS Infection Risk Index has been applied in Brazilian studies that aimed to predict infection risks in some types of specific surgeries, such as cardiothoracic, cardiovascular, digestive, neurological and pediatric surgeries(17-20). Results were controversial. In all of these studies, other specific variables had to be included for each type of procedure, which permitted the construction of alternative surgical infection risk prediction models. One of the reasons to assess the infection prediction power of the NNIS Risk Index in specific surgeries is due to its easy applicability in daily hospital practice ${ }^{(15)}$.

The goal of this study was to assess the NNIS Risk Index to predict SSI in patients submitted to orthopedic surgeries, as well as to promote an alternative index for application at the study hospitals.

\section{Methods}

\section{Design and Study Variables}

In a historical cohort, information on 8,236 patients submitted to general orthopedic surgical procedures, classified as NNIS procedures. This were inserted in the database of a hospital infection control program called Computerized Hospital Infection Control System $\mathrm{SACIH}^{(15)}$. These patients were attended at four general and teaching hospital for tertiary care delivery, located in different regions of Belo Horizonte, Minas Gerais, Brazil.

The response variable under analysis was the presence or absence of SSI. The following independent variables were assessed: hospital (coded as 0,1,2,3); ASA (I, II, III, IV and V, according to the American Society of Anesthesiologists' criterion); surgical wound contamination potential (clean, potentially clean, contaminated and infected); duration of surgery ( $\leq 120$ and $\geq 120$ minutes); prosthesis (no and yes); type of surgical procedure (FUS = fusion and arthrodesis; $F X=$ reduction of open fracture; OMS = other procedures in the musculoskeletal system; PROS-Q = hip prosthesis, PROS-O = other types of prosthesis and PROS-J= knee prosthesis); number of professionals during the surgery (1-4, 5-8, 9-16 professionals); antibiotic prophylactics (no, use of cefazoline, use of clindamycin and associates); trauma (no, yes); general anesthesia (no, yes); age (in years, continuous); preoperative time (in minutes, continuous). The NNIS Surgical Infection Risk Index (comprising ASA, surgical wound contamination potential and surgery duration) was analyzed according to its categories: score 0 (three absent factors), score 1 (only one factor present), score 2 (two factors presents), score 3 (three factors present). This Index attributes scores 0 and 1 , according to the presence or absence of the risk factor.

\section{Statistical Analysis}

STATA 8.1 software was used for statistical data analysis $^{(21)}$. Simple frequency distribution, central trend measures (mean or median) and variability measures (standard deviation, quartiles and minimum and maximum values) were used to characterize and describe the patients submitted to orthopedic surgeries.

Global incidence levels were calculated per NNIS Surgical Infection Risk Index-category, hospital and type of surgical procedure. For calculation purposes, the number of SSI cases among orthopedic surgical patients was used as the numerator, while the total number of orthopedic surgical patients during the study period was used as the denominator.

Univariate and multivariate analyses were conducted, using logistic regression with a view to developing SSI prediction models(22). In the multivariate analysis, initial modeling was based on the variables selected in the univariate analysis (statistical association 
with SSI and $p \leq 0.20$ ), as well as variables that did not show statistically significant differences but are described in literature as associated with surgical site infection. Variables with more than two categories were transformed into indicative variables called "dummies"(22).

First, the complete model was constructed. Then, the variables were removed step by step until the final model was defined. To define the best final model, the likelihood-ratio test was used, as well as the $\beta$ (Beta) coefficients, odds ratio (OR) and $p<0.05^{(22)}$.

ROC "Receiver Operating Characteristic Curve" analysis was the method chosen to assess the accuracy (discriminatory power between individuals with and without the event under analysis) of the alternative SSI prediction models) ${ }^{(23)}$. To check the strength of the correlation between the NNIS Surgical Infection Risk Index and SSI occurrence, the Goodman-Kruskal (G) test - Gamma Coefficient was used. This test is particularly adequate to analyze variables with an ordinal measurement level, like in the case of the risk ratio under analysis. It ranges between -1 and +1 . If the analyzed variables are independent, the coefficient is close to zero(24).

After obtaining the best alternative SSI risk prediction model, the ROC Curve of the new predictive model was compared with the ROC Curve of the NNIS Surgical Infection Risk Index model.

It should be highlighted that, at the four hospital, no post-hospital discharged monitoring of surgical patients is accomplished.

Approval for the research project was obtained from the Institutional Review Board at UFMG (process ETIC 274).

\section{Results}

\section{Characterization of orthopedic surgical patients and SSI Incidence}

The patients' average age was 34.6 years (sd: 27), ranging from 0 (younger than 1 year) to 99 years, with a median age of 30 years (quartiles 1 and 3: 10 and 57). The mean preoperative hospitalization time was 3.8 days (sd: 25.6), ranging from 0 to 595 days, with a median time of 1 day (quartiles 1 and 3: 0 and 1).

Among the 8,236 patients who submitted to orthopedic surgical procedures, 116 surgical site infections (SSI) were identified. The global infection incidence level was $1.41 \%$ ( $95 \%$ confidence interval: 1.18 - 1.76) for the study period.

SSI incidence levels for the orthopedic procedures were: $2.2 \%$ for PROS-Q and PROS-O; $1.7 \%$ for OMS; $1.5 \%$ for PROS-J; $1.4 \%$ for FUS and $1.1 \%$ for FX.

In the analysis of SSI per hospital, the highest SSI incidence level was verified at hospital, with $2.0 \%$ $(n=56)$. At the other hospitals, SSI incidence levels were: hospital 2 with $1.8 \%(n=10)$; hospital 3 with $1.2 \%(n=11)$ and hospital 1 with $1.0 \%(n=39)$.

\section{NNIS Surgical Infection Risk Index}

SSI incidence levels per NNIS Index Ratio category were: score $0=1.1 \%$; score $1=1.8 \%$; score $2=2.8 \%$; score $3=5.3 \%$. A linear increase in incidence levels was observed to the extent that the risk factors of the NNIS Index increase. An assessment of the NNIS Index' efficiency in the 8,236 orthopedic surgical patients showed that this ratio layered patients in only three of its four risk categories.

The analysis of the NNIS Risk Index for specific orthopedic procedures (FUS, FX, OMS, PROS-Q, PROS-O and PROS-J) revealed the inefficiency of this ratio to stratify patients submitted to these six procedures among its four categories. This fact may be due to the characteristic of the study sample or the Index' deficient SSI prediction when the even under analysis is rare. The NNIS Index divided patients in only two layers (score 0 and score 1 ). Less than $8 \%$ of patients were classified in score 2. No patients were classified in score 3 for FUS, PROS - J, PROS - O and PROS - Q procedures.

In the NNIS Risk Index variable, score 0 (patients without any risk factor) was considered a reference for the univariate analysis. An upward trend in the OR was observed as the number of risk factors for each score increases (Table 1 ). Nevertheless, patients classified as score 3 showed OR=5.2 ( $95 \%$ confidence interval: 0.7 $39.4, p=0.11$ ). This score, however, showed no statistical significance for SSI, as only one infected patient was classified as score 3.

Table 1 - Logistic regression estimates for NNIS/CDC Surgical Infection Risk Index assessment, Belo Horizonte, Brazil

\begin{tabular}{|c|c|c|c|c|}
\hline Variable & Coefficient & OR & P-value & $95 \%$ confidence interval \\
\hline \multicolumn{5}{|l|}{ NNIS Risk Index } \\
\hline NNIS Risk Index_1 & 0,568 & 1,76 & 0,004 & $1,2-2,6$ \\
\hline NNIS Risk Index_2 & 0,979 & 2,66 & 0,002 & $1,4-5,0$ \\
\hline NNIS Risk Index_3 & 1,642 & 5,16 & 0,113 & $0,7-39,4$ \\
\hline
\end{tabular}


The accuracy of the NNIS Index was also assessed through the ROC "Receiver Operating Characteristic Curve". The area under the curve represents the distinction of all possible pairs of individuals with SSI or not. The probability is measured that a patient with SSI will present a higher (estimated probability) than the of a patient without infection. The higher the area, the greater the corresponding model's predictive capacity.

The model called NNIS Index (ASA, surgical wound contamination potential and duration of surgery) displayed 0.58 for the area under the corresponding curve, indicating low power to predict infected patients. The NNIS Risk Index was analyzed through the Gamma Coefficient. The result ( $\mathrm{G}=0.31 ; 95 \%$ confidence interval: $0.154-0.455, p=0.000$ for Chi-square $-X^{2}$ distribution with 3 degrees of freedom - gl) was considered very low (Table 2), in line with what shown in the area under the ROC Curve (Figure 1).

Table 2 - Assessment of Correlation between NNIS Index and SSI of patients submitted to orthopedic surgical procedures, using the Goodman-Kruskal Test (G) - Gamma Coefficient, Belo Horizonte, Brazil

\begin{tabular}{lccccc}
\hline SSI & \multicolumn{5}{c}{ NNIS Surgical Infection Risk Index } \\
\hline \multirow{2}{*}{$0-$ No } & $\mathbf{0}$ & $\mathbf{1}$ & $\mathbf{2}$ & $\mathbf{3}$ & Total \\
& $(64.13 \%)$ & $(30.49 \%)$ & $(5.16 \%)$ & $(0.22)$ & $(100 \%)$ \\
1 - Yes & 56 & 47 & 12 & 01 & 116 \\
& $(48.28 \%)$ & $(40.52 \%)$ & $(10.34 \%)$ & $(0.86 \%)$ & $(100 \%)$ \\
Total & & & & & \\
& 5,263 & 2,523 & 431 & 19 & 8,236
\end{tabular}

Pearson $\mathrm{X}^{2}(\mathrm{gl}=3)=16.2, \mathrm{p}=0.001 ; \mathrm{G}=0.31 ; 95 \%$ confidence interval: $(0.154-0.455), p \leq 0.000$; Standard Error $=0.077$.

In general, it can be inferred that the NNIS Index moderately stratifies orthopedic surgical patients. The model, however, was not a good infection predictor, as the estimated incidence levels were very low.

\section{Alternative Models}

Based on the univariate analysis results, initially, seven variables were selected for the alternative models, according to the established statistical significance $(p \leq 0.20)$. These were: ASA, prosthesis, surgical wound contamination potential, NNIS Surgical Infection Risk Index, antibiotic prophylaxis, hospital and number of professionals during the surgery. Seven other variables of acknowledged importance in literature comprised the multivariate logistic regression analysis. These were: procedure type, trauma, emergency nature of the surgery, general anesthesia, age, preoperative hospitalization time and duration of surgery.

Based on these variables, four SSI risk prediction models were specified, which were compared with the NNIS Index model. Only one of the four constructed models effectively predicted SSI risk.

All possible interactions among the variables included in the model were tested. To obtain the final alternative model, the researchers decided to remove all statistically significant interactions, such as ASA and hospital, surgical wound contamination potential and prosthesis, hospital and number of professionals during the surgery, due to the collinearity between each interaction and with other variables in the database.

Variables like trauma, emergency nature of the surgery, preoperative time, procedure type, age and antibiotic prophylaxis were removed from the full model, one by one in the presented order, with $p<0.05$. The final alternative model included the following variables: ASA, prosthesis, surgical wound contamination potential, hospital, number of professionals during the surgery, general anesthesia and duration of the surgery. Table 3 shows the logistic regression estimated for this model, represented in the ROC Curve for the sake of a better visualization of the results (Figures 1 and 2).

The likelihood-ratio test indicated that the general anesthesia variable, although not statistically significant, should return to the final alternative model with a view to a better adjustment.

The analysis of the area under the curve in the alternative model shows that it gets closer to the upper left border of the graph when compared with the NNIS model. The alternative model showed an area of 0.75 under the curve, revealing good accuracy or good predictive power of the test to detect patients with SSI (Figures 1 and 2).

Table 3 - Logistic regression estimates to define the Alternative Predictive Model, Belo Horizonte, MG

\begin{tabular}{lcccc}
\hline \multicolumn{1}{c}{ Variable } & Coefficient & OR & P value & Confidence Interval 95\% \\
\hline Prosthesis (yes) & 0.628 & 1.87 & 0.00 & $1.3-2.9$ \\
ASA & & & 0.01 & $1.2-3.1$ \\
$\quad$ Asa 2 & 0.633 & 1.88 & 0.00 & $1.7-5.8$ \\
$\quad$ Asa 3 & 1.111 & 3.03 & 0.02 & $1.4-17.3$ \\
$\quad$ Asa 4 & 1.576 & 4.83 & & $0.7-1.7$ \\
Number of professionals during surgery & & & 0.78 & $1.7-14.5$ \\
$\quad$ 5-8 & 0.065 & 1.06 & 0.00 & (continue...) \\
9-16 & 1.667 & 5.29 & &
\end{tabular}


Table 3 - continuation

\begin{tabular}{lcccc}
\hline \multicolumn{1}{c}{ Variable } & Coefficient & OR & P value & Confidence Interval 95\% \\
\hline Hospital & & & & $0.1-0.3$ \\
$\quad$ Hospital 1 & -1.758 & 0.17 & 0.09 & $0.3-1.1$ \\
$\quad$ Hospital 2 & -0.655 & 0.52 & 0.00 & $0.1-0.6$ \\
$\quad$ Hospital 3 & -1.363 & 0.26 & & $1.3-4.4$ \\
Potential surgical wound contamination & & & 0.00 & $2.2-10.6$ \\
$\quad$ Potentially contaminated & 0.904 & 2.47 & 0.00 & $1.9-7.4$ \\
$\quad$ Contaminated & 1.564 & 4.78 & 0.00 & $0.5-1.0$ \\
$\quad$ Infected & 1.347 & 3.85 & 0.06 & $1.1-2.6$ \\
General Anesthesia (yes) & -0.383 & 0.68 & 0.03 & \\
Duration of surgery (minutes) & 0.503 & 1.65 & & \\
\hline
\end{tabular}

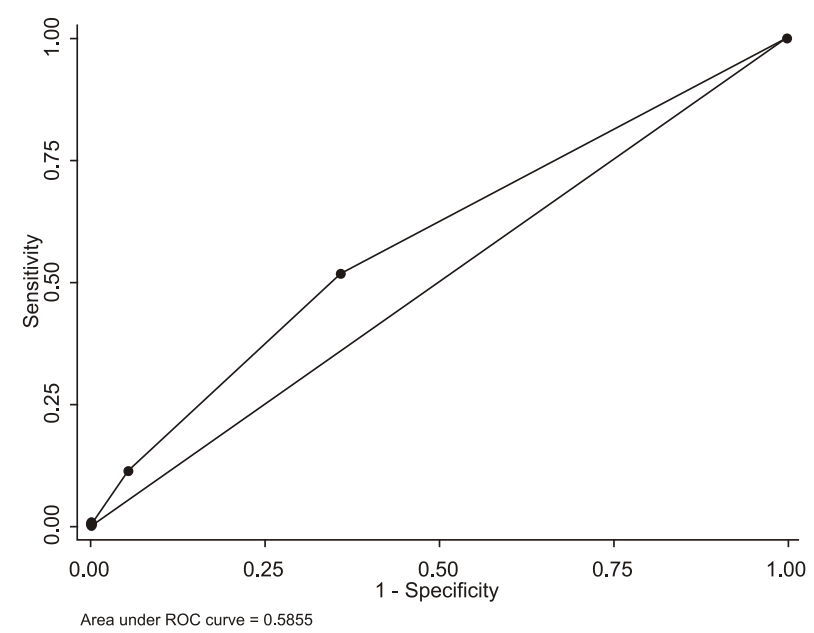

Figure 1 - ROC Curve - NNIS Surgical Infection Risk Index

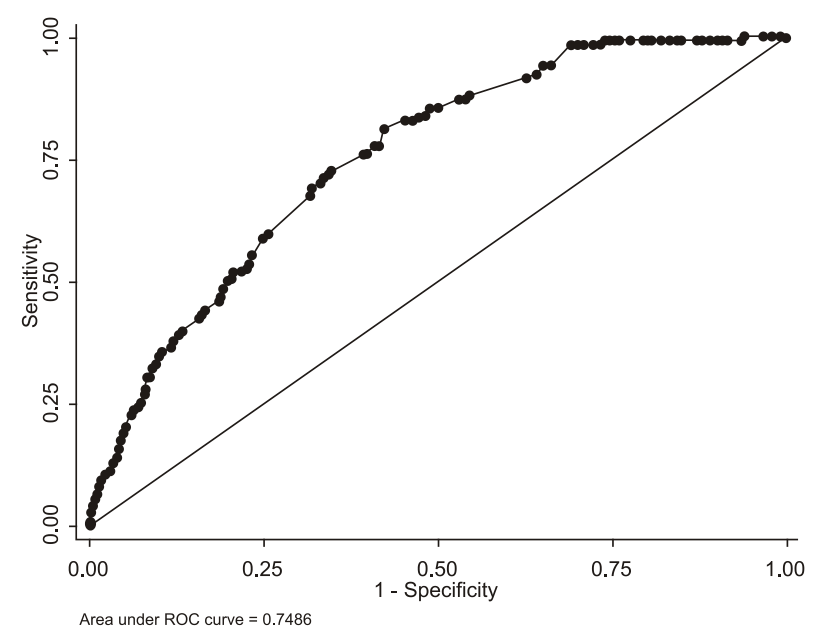

Figure 2 - ROC Curve - Alternative Model

\section{Discussion}

The global SSI incidence at the four study hospitals was $1.41 \%$. This level, resulting from patient surveillance during hospitalization, remains below levels found in different studies ${ }^{(4-9)}$.

It is highlighted that these low levels can reflect effective and consolidated epidemiological surveillance at the research hospitals, but can also derive from infection under-notification, due to the lack of patient control after hospital discharge and to registration problems in the hospital databases ${ }^{(4,20)}$.

SSI patients stratified according to the NNIS Index showed a low but increasing incidence level. SSI incidence levels rose for scores $0,1,2$ and 3, corresponding to $1.1 \%, 1.8 \%, 2.8 \%$ and $5.3 \%$, respectively. Incidence levels were expected to increase with risk factors. Also, growing SSI rates were found in a study as the risk factors of the NNIS Index increased(14).

The analysis of the NNIS Index' stratification power for the six orthopedic procedure types (FUS, FX, OMS, PROS-Q, PROS-O and PROS-J) showed that it stratified the orthopedic surgical patients in only three layers in four out of six procedures. Different studies have shown inadequacies in the NNIS Index, affirming this index' general inability to predict SSI risk in different types of surgical procedures ${ }^{(16-17,20)}$

The use of the NNIS Index in a wide range of procedures does not permit extending the results to specific populations and procedures. To analyze specific procedures with characteristic peculiarities, more adequate SSI prediction models for these particular situations should be created(16-20).

The NNIS Index showed no statistical association with SSI. According to the Goodman-Kruskal (Gamma), low predictive power of the SSI is observed for orthopedic surgical patients $(G=0.31)$. The confirmation of this result is displayed in the area under the ROC Curve, calculated at $58 \%$. In conclusion, the power of the NNIS Index to discriminate true positive patients for SSI is low. A similar result was found in a prospective cohort of digestive surgery patients ${ }^{(20)}$.

This study proposed an alternative infection risk prediction model for orthopedic surgery patients. The suggested alternative model contains, besides the three variables of the NNIS Index (ASA, surgical wound contamination potential and duration of the surgery), three other variables (prosthesis, number of 
professionals during the surgery, general anesthesia and hospital) that better adjusted the alternative model. The SSI prediction power of the alternative model was superior in comparison with the NNIS model(20).

The SSI's discriminatory power to detect true positive cases in the chosen model was calculated and also visualized through the ROC Curve. The $75 \%$ score (95\% confidence interval: $0.71-0.79, \mathrm{p}<0.05$ ) shows that this model is a better infection predictor when compared with the NNIS model.

\section{Conclusions}

The alternative model performed better than the NNIS model for SSI risk prediction purposes. It contains a larger number of variables, however, in comparison with the NNIS model. This fact can represent a disadvantage, as it demands more time for data collection, entails possible errors to include information into the databases and, sometimes, the responsible professionals do not complete the data collection instruments, compromising the quality of the produced data.

The hospital variable, present in the alternative model, deserves further assessment as, in this study, data from four different hospitals with different SSI ratios were assessed.

In Brazil, research on the adequacy of the NNIS Index to predict infection risk in specific surgical procedures is scarce. These study results can contribute to the Hospital Infection Surveillance and Control Services at the study institutions, to the extent that the study questions the assessment and determination of patients' risk of contracting SSI according to the NNIS Index and proposes adaptations. The need is emphasized to validate the alternative model before its application in these hospitals' clinical practice. For the sake of this validation, a prospective and multicenter study should be carried out at hospitals in Belo Horizonte, Minas Gerais, Brazil.

\section{References}

1. Centers for Diseases Control and Prevention. The National Healthcare Safety Network Manual - NHSN. Pacient Safety Component Protocol. Division of Healthcare Quality Promotion National Center for Preparedness, Detection and Control of Infectious Diseases Atlanta, GA, USA 2009. 225p. [acesso: março 2009]. Disponível em: http://www.cdc.gov.

2. Agência Nacional de Vigilância Sanitária (BR). Critérios Nacionais de Infecções Relacionadas à
Assistência. Brasília (DF): Ministério da Saúde; 2009. 84 p. [acesso: 25 jan. 2008]. Disponível em: http:// www.anvisa.gov.br.

3. Knobben BAS, Van Horn Jr, Van Der Mei HC, Busscher $\mathrm{HJ}$. Evaluation of measures to decrease intra-operative bacterial contamination in orthopaedic implant surgery. J Hosp Infect. 2006;62(2):74-80.

4. Ercole FF, Chianca TCM. Infecção de sítio cirúrgico em pacientes submetidos à artroplastia de quadril. Revista Latino-Am. Enfermagem. 2002;10(2):157-65.

5. Lima ALLM, Zumiotti AV, Uip DE, Silva JS. Fatores preditivos de infecção em pacientes com fraturas expostas nos membros inferiores. Acta Ortop Bras. 2004;12(1):23-39.

6. Maksimovic J. Incidence of surgical site infections in the departaments of orthopedics and traumatology. Vojnosanit Pregl. 2006;63(8):725-9.

7. Maksimovic J, Markovíc-Denic L, Bumbasrevic M, Marinkovic J, Vlajinac $H$. Surgical site infections in orthopedics patients: prospective cohort study. Croat Med J. 2008;49(1):58-65.

8. Zimmerli W, Trampuz A, Ochsner PE. Prosthetic-joint infections. N Engl J Med. 2004;351:1645-54.

9. Dolinger EJOV. Infecções Ortopédicas em pacientes submetidos a artroplastias total de quadril e joelho, hemiartroplastias e osteosínteses: incidência, fatores de risco e influência do ar do centro cirúrgico em um Hospital Universitário Brasileiro. [dissertação]. Uberlândia (MG): Departamento de Imunologia e Parasitologia Aplicada da Universidade Federal de Uberlândia; 2008. 73 p.

10. Conway WA. Back to basics: giving attention to surgical infection prevention. Mich. Health Hosp. 2003;39(4):40-2.

11. Gaynes RP, Culver DH, Horan TC, Edwards JR, Richards C, Tolson JS. Surgical-site infections (SSI) rates in the United States, 1992-1998: the National Nosocomial Infections Surveillance System basic SSI Risk Index. Clin Infect Dis. 2001;33 Suppl 2:69-77.

12. Haley RW, Culver DH, Morgan WM, White JW, Emori TG, Hooton TM. Identifying patients at high risk of surgical wound infection. Am J Epidemiol. 1985; 121(2):206-15.

13. Nichols RL. Preventing Surgical Site Infections. Clin Med Res. 2004; 2(2):115-8.

14. Freitas PF, Campos ML, Cipriano, ZM. Aplicabilidade do índice de risco do Sistema NNIS na predição de risco da incidência de infecção do sítio cirúrgico (ISC) em um hospital universitário no sul do Brasil. Rev Assoc Med Bras. 2000; 46(4):359-62.

15. Starling CEF, Couto BRGM, Pinheiro SMC. Applying the 
Centers for Disease Control and Prevention and National Nosocomial Surveillance System methods in Brazilian hospitals. Am J Infect Control. 1997;25:303-11.

16. Roy MC, Herwaldt LA, Embrey R, Kuhns R, Wenzel RP, Perl TM. Does the centers for Disease Control's NNIS System Risk Index stratify patients undergoing cardiothoracic operations by their risk of surgical-site infection? Infect Control Hosp Epidemiol. $2000 ; 21(3): 186-90$.

17. Vernet E, Adell C, Trilla A, Zaragoza M, Salles $M$, Jimenez De Anta MT, et al. Utilidad de los indices compuestos de riesgo para predecir el desarrollo de infección quirúrgica en neurocirugía. Med Clin Barc. 2004;122(3):92-5.

18. Friedman $D N$, Bull $A L$, Gurrin L, Richards $M$. Performance of The National Nosocomial Infections Surveillance Risk Index in Predicting Surgical Site Infections in an Australia. Am J Infect Control. 2005;33(5): 180-1.

19. Starling CEF, Couto B, Crisóstomo MS, Fortes D. Evaluación del índice de riesgo de infección quirúrgica (IRIQ) en la cirugía pediátrica. Rev Cir Infant. $1996 ; 6(4): 181-7$.

20. Oliveira AC, Ciosak SI, Ferraz EM, Grinbaum S. Surgical site infection in patients submitted to digestive surgery: Risk prediction and the NNIS risk index. Am J Infect Control. 2006 May; 34(4):201-7.

21. Statacorp. Stata Statistical Software: release 8.1. College Station, Texas: Stata Corporation; 2003.

22. Hosmer JR, David W, Lemeshow S. Applied logistic regression. New York: John Wiley; 1989. 307 p.

23. Hanley JA, Mcneil BJ. The meaning and use of the area under a receiver operating characteristic (ROC) curve. Radiology. 1982;50:23-6.

24. Goodman LA, Kruskal WH. Measures of association for cross classifications. J Am Stat Assoc. 1954;49:732-64. 